\title{
JPT1 Gene
}

National Cancer Institute

\section{Source}

National Cancer Institute. JPT1 Gene. NCI Thesaurus. Code C114589.

This gene plays a role in signaling, cell cycle and cell adhesion. 